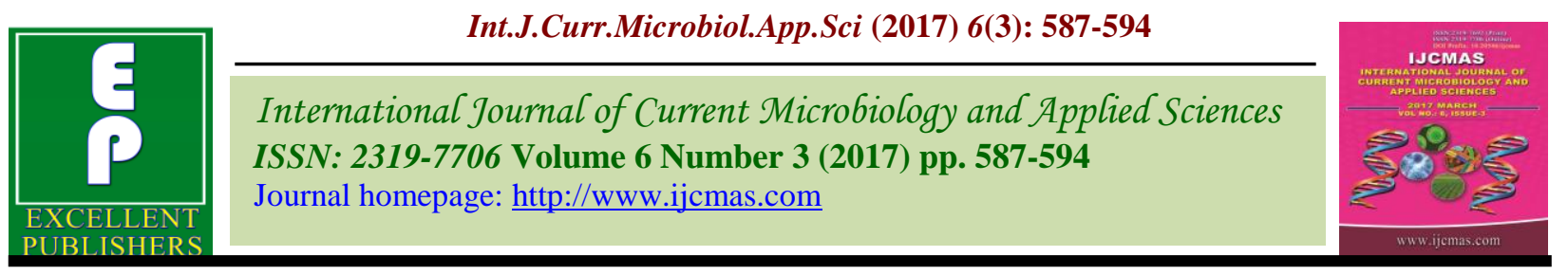

Original Research Article

https://doi.org/10.20546/ijcmas.2017.603.068

\title{
Identification of Yeast Strain Isolated from Nduiyi of Dima Hasao District of Assam, India
}

\author{
Jayasree Chakrabarty* \\ Department of Botany, Cotton College, Guwahati, Assam, India \\ *Corresponding author
}

\section{A B S T R A C T}

\begin{tabular}{|l|}
\hline K e y w o r d s \\
Nduiyi; starter; \\
Nduijao, Alcoholic \\
beverage; Jeme naga, \\
Dima Hasao \\
(formerly, North \\
cachar Hills), Yeasts.
\end{tabular}

Nduiyi is a traditional amylolytic starter used to produce sweet-sour alcoholic beverage, called Nduijao by Jeme Naga in Dima Hasao (formerly, North Cachar Hills) district of Assam. The aim of this study was to examine the Yeast flora present in Nduiyi collected from Dima Hasao district of Assam. Total 4 samples of Nduiyi was collected from Jeme Naga villages of the Hill district. Based on cell morphology and Phenotypic characterization isolates were identified as Candida glabrata and Saccharomyces cerevisae. It was hypothesized that both the groups of Yeast have a primary role in alcohol fermentation.

\section{Introduction}

Nduiyi is a traditionally prepared mixed amylolytic dough inocula used as a starter by the Jeme Naga tribe of Dima Hasao district of Assam for the production of indigenous alcoholic beverage the Nduijao. During the traditional method of preparation, bark of Albizia myriophylla Benth. (Family Mimosaceae) or leaves of Saccharum officinarum L. (Family - Poaceae) is used. These are dry, flat- rounded and oval, creamy white to dusty white, solid starter ranging from $1.1 \mathrm{~cm}$ to $10.1 \mathrm{~cm}$ in diameter with the weight ranging from $15 \mathrm{~g}$ to $25 \mathrm{~g}$. The method of preparation is as follows: Sticky rice is soaked for $9-10 \mathrm{~h}$ at room temperature and crushed with bark of Albizia myriophylla or leaves of Saccharum officinarum and 2-3\% of previously prepared Nduiyi as mother culture. The mixture is then made into paste by adding water and kneaded into flat rounded and oval cakes of varying sizes and kept it for one to three days at $25-30^{\circ} \mathrm{C}$ and sun dried for two to three days. Finally, cakes are stored in a dry place for more than a year. Nduiyi is also similar to traditional mixed amylolytic starters such as humao of Dima Hasao(Chakrabarty et al.,,2014), marcha of Sikkim (Tamang and Sarkar, 1996) \&, ragi of Indonesia (Saono et al., 1974).

The present study investigated the Yeast present in Nduiyi of Dima Hasao district and 
their possible roles in production of popular indigenous alcoholic beverages of the Hill district.

\section{Socio-economy}

Nduiyi is produced at home and is sold in local periodical markets exclusively by the rural women. Cost of a single Nduiyi (size, $15-25 \mathrm{~g}$ ) is around Rs.10-20/ depending on size.

\section{Ethnic value}

In any religious festivals, the ethnic people offer Nduiyi(starter) to each male and female in the name of family God and Goddesses.

\section{Materials and Methods}

\section{Collection of Samples}

A field survey was conducted in different Jeme Naga villages of Dima Hasao district. Different samples of Nduiyi were collected from different Jeme Naga villages as well as local market. All samples were collected aseptically in pre-sterile poly-bags transported to laboratory for analyses.

\section{Isolation of yeasts}

Ten $\mathrm{g}$ of sample were homogenized with 90 $\mathrm{ml}$ of $0.85 \%(\mathrm{w} / \mathrm{v})$ sterile physiological saline in a stomacher lab-blender (400, Seward, UK) for $1 \mathrm{~min}$. A serial dilution $\left(10^{-1}\right.$ to $\left.10^{-8}\right)$ in the same diluent was made.

Enumeration and isolations were targeted for Yeast. Yeasts were isolated on yeast-malt extract (YM) agar (M424, HiMedia), supplemented with $10 \mathrm{IU} / \mathrm{ml}$ benzylpenicillin and $12 \mu \mathrm{g} / \mathrm{ml}$ streptomycin sulphate, respectively; and plates were incubated aerobically at $28^{\circ} \mathrm{C}$ for $72 \mathrm{~h}$ (Tsuyoshi et al., 2005).

\section{Morphological characterisation}

Morphological studies of yeast isolates were performing using yeast -malt extract (YM) agar and YM broth (Difco Laboratories), incubated at $25^{\circ} \mathrm{C}$ for $72 \mathrm{~h}$. To induce the sporulations of yeasts, acetate agar, corn meal agar, Gorodokowa agar, 5\% malt agar, potato -dextrose agar, vegetable juice agar, and YM agar were used according to Yarrow (1998).

\section{Physiological and biochemical characterization}

Physiological and biochemical characteristics of the yeasts isolates were determined according to the API test (API 20C AIX;BioMerieux S.A., Marcy- 1'Etoile, France) and the method described by Yarrow (1998).

\section{Ethanol production}

The ethanol yield of yeast isolates was determined after growth at $25^{\circ} \mathrm{C}$ for $4 \mathrm{~d}$ in YM broth containing 10\% glucose. Ethanol concentration in the culture supernatant was determined by the enzyme assay (F-Kit Ethanol; Roche Diagnostics K.K., Tokyo, Japan).

\section{Results and Discussion}

Nduiyi is used as a starter for the preparation of Nduijao (ethnic fermented beverages of Dima Hasao used by Jeme Naga. It has been observed that Yeast present in the starter were high in numbers. It is exclusively prepared by the rural women belonging to the Lodi, Asalu, Nutan Gunjung, Boro haflong, Lisong basti of Dima Hasao.

Based on morphological and physiological characterization the yeast strains were identified Different samples of Nduiyi (mixed amylolytic starter) of Dima Hasao district of 
Assam were analysed for Yeast (Table 1) population. The average yeast population in Nduiyi were found at the level of $10^{8} \mathrm{Log}$ $\mathrm{cfu} / \mathrm{g}$ in all the samples, lactic acid bacteria was comparatively less $\left(\sim 10^{5} \mathrm{cfu} / \mathrm{g}\right)$, Bacilli were at the level of $10^{6} \mathrm{cfu} / \mathrm{g}$, and mould at the level of $10^{7} \mathrm{cfu} / \mathrm{g}$. Filamentous moulds were not recovered in any finish product of Nduijao indicating that moulds have roles only in the initial phase of fermentation mostly in saccharification of the substrates. The $\mathrm{P}^{\mathrm{H}}$ of Nduijao (alcoholic beverage) was $4.3 \pm 0.1$, titratable acidity was $0.44 \pm 0.01$ and alcohol percentage was 4.0-6.0. Mineral (copper, chromium, manganese, iron, zinc, magnesium, potassium, sodium, lead, nickel and selenium) present in uncooked rice and in fermented beverage i.e. Nduijao was estimated. The result showed higher content of minerals in fermented beverage than that of raw substrate.
The morphological and physiological characteristics identified the isolates as Saccharomyces cerevisae \& Candida glabrata. Amylolytic and alcohol-producing yeast isolated from humao was Saccharomyces cerevisae (Chakrabarty et al., 2014).

In this study, phenotypic studies of the Yeasts isolated from Nduiyi demonstrated that the amylolytic starters constituted more diverse microflora than previously recognised. The yeast species identified were $S$. cerevisae and C. glabrata. The identified yeast species, $S$. bayanus and $C$. glabrata were also encountered in and isolated from several other Asian amylolytic starters (Deak, 1991; Hadisepoetro et al., 1979; Hesseltine et al., 1988; Hesseltine and Kurtzman, 1990).

Table.1 Microbial populations of Nduiyi (mixed amylolytic starter) and Nduijao, fermented alcoholic beverage of Dima Hasao district of Assam

\begin{tabular}{|c|c|c|c|c|c|}
\hline Product & Collection & $\begin{array}{c}\text { LAB } \\
\text { Log } \\
\text { cfu/g }\end{array}$ & $\begin{array}{c}\text { Bacilli } \\
\text { Log cfu/g }\end{array}$ & $\begin{array}{c}\text { Yeast Log } \\
\text { cfu/g }\end{array}$ & $\begin{array}{c}\text { Mould } \\
\text { Log cfu/g }\end{array}$ \\
\hline \multirow[t]{2}{*}{ Nduiyi } & $\begin{array}{c}\text { Haflong } \\
\text { bazaar } \\
(\mathrm{n}=2)\end{array}$ & $5.9 \pm 0.06$ & $6.8 \pm 0.0$ & $8.2 \pm 0.06$ & $7.2 \pm 0.0$ \\
\hline & $\begin{array}{l}\text { Lodi } \\
\text { basti } \\
(\mathrm{n}=2)\end{array}$ & $5.8 \pm 0.0$ & $6.8 \pm 0.06$ & $8.3 \pm 0.0$ & $7.3 \pm 0.06$ \\
\hline \multirow[b]{2}{*}{ Nduijao } & $\begin{array}{c}\text { Haflong } \\
\text { bazar } \\
(\mathrm{n}=2)\end{array}$ & $5.2 \pm 0.06$ & $6.8 \pm 0.06$ & $7.5 \pm 0.0$ & NIL \\
\hline & $\begin{array}{c}\text { Laisong } \\
\text { basti } \\
(\mathrm{n}=2)\end{array}$ & $5.2 \pm 0.06$ & $6.8 \pm 0.06$ & $7.4 \pm 0.06$ & NIL \\
\hline
\end{tabular}

$\mathrm{n}=$ number of samples. Data represents the means $( \pm \mathrm{SD})$ of samples. 
Table.2 Identification of yeasts isolated from Nduiyi

\begin{tabular}{|c|c|c|c|c|c|c|c|c|c|c|c|c|c|c|c|c|c|c|c|c|c|c|c|c|c|c|c|}
\hline \multirow[b]{2}{*}{ 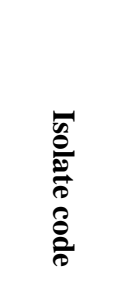 } & \multirow[b]{2}{*}{ Cell size $(\mu \mathrm{m})$} & \multirow[b]{2}{*}{ Ascospore } & \multirow[b]{2}{*}{ 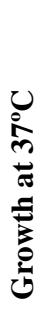 } & \multicolumn{8}{|c|}{ Sugars Fermented } & \multicolumn{15}{|c|}{ Sugars Assimilated } & \multirow[b]{2}{*}{ Identity } \\
\hline & & & & 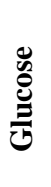 & 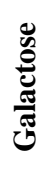 & 苞 & 离 & 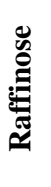 & 总 & 离 & 总 & 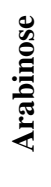 & Uू. & 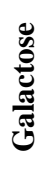 & 苞 & ?: & 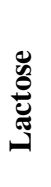 & 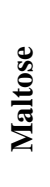 & 芦 & 总 & 苟 & 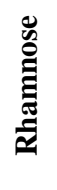 & 岕 & 萢 & 离 & $\frac{\ddot{0}}{2}$ & \\
\hline DHN:Y1 & $\begin{array}{l}1=4.5(3.2-5.4) \\
b=2.8(1.6-4.7)\end{array}$ & Globose & + & + & + & - & + & + & + & + & - & - & - & + & + & - & $\mathrm{w}$ & + & + & - & + & - & + & $\mathrm{w}$ & + & - & $\begin{array}{l}\text { Saccharomyces } \\
\text { cerevisiae }\end{array}$ \\
\hline DHN:Y2 & $\begin{array}{l}\mathrm{l}=4.7(3.2-5.6) \\
b=2.4(1.6-4.8)\end{array}$ & Globose & + & + & + & - & + & + & + & + & - & - & - & + & + & - & - & + & + & - & + & - & + & + & + & - & $\begin{array}{l}\text { Saccharomyces } \\
\text { cerevisiae }\end{array}$ \\
\hline DHN: Y3 & $\begin{array}{l}\mathrm{l}=3.5(1.6-4.0) \\
\mathrm{b}=2.8(1.5-3.2)\end{array}$ & Globose & + & + & - & - & - & - & - & - & + & - & - & + & - & - & - & + & + & - & - & - & - & + & $\mathrm{w}$ & - & $\begin{array}{l}\text { Candida } \\
\text { glabrata }\end{array}$ \\
\hline DHN:Y4 & $\begin{array}{l}\mathrm{l}=3.7(1.5-4.2) \\
b=2.5(1.2-3.3)\end{array}$ & Globose & + & + & - & - & - & - & - & - & + & - & - & + & - & - & - & + & $\mathrm{w}$ & - & - & - & - & + & + & - & $\begin{array}{l}\text { Candida } \\
\text { glabrata }\end{array}$ \\
\hline
\end{tabular}




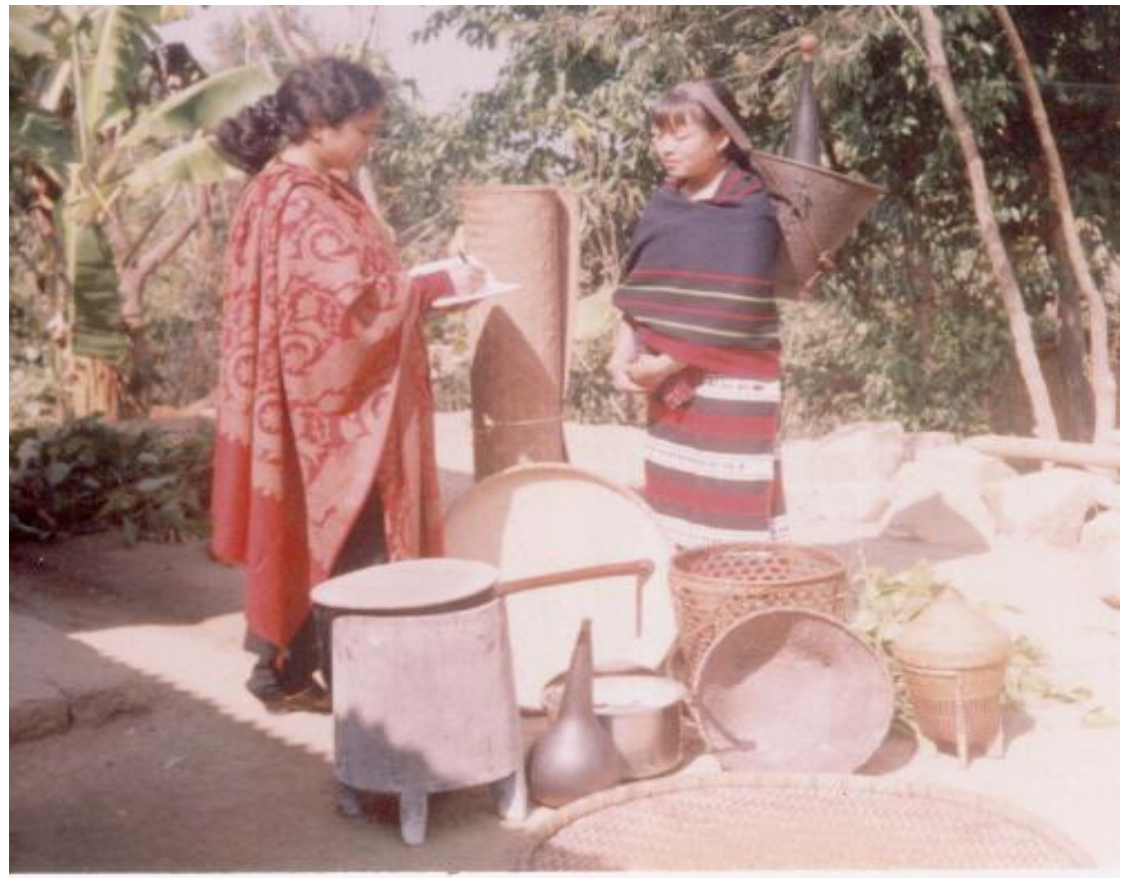

(a) J. Chakrabarty taking a interview with a Naga woman in a Naga village of Haflong town (Dima Hasao )

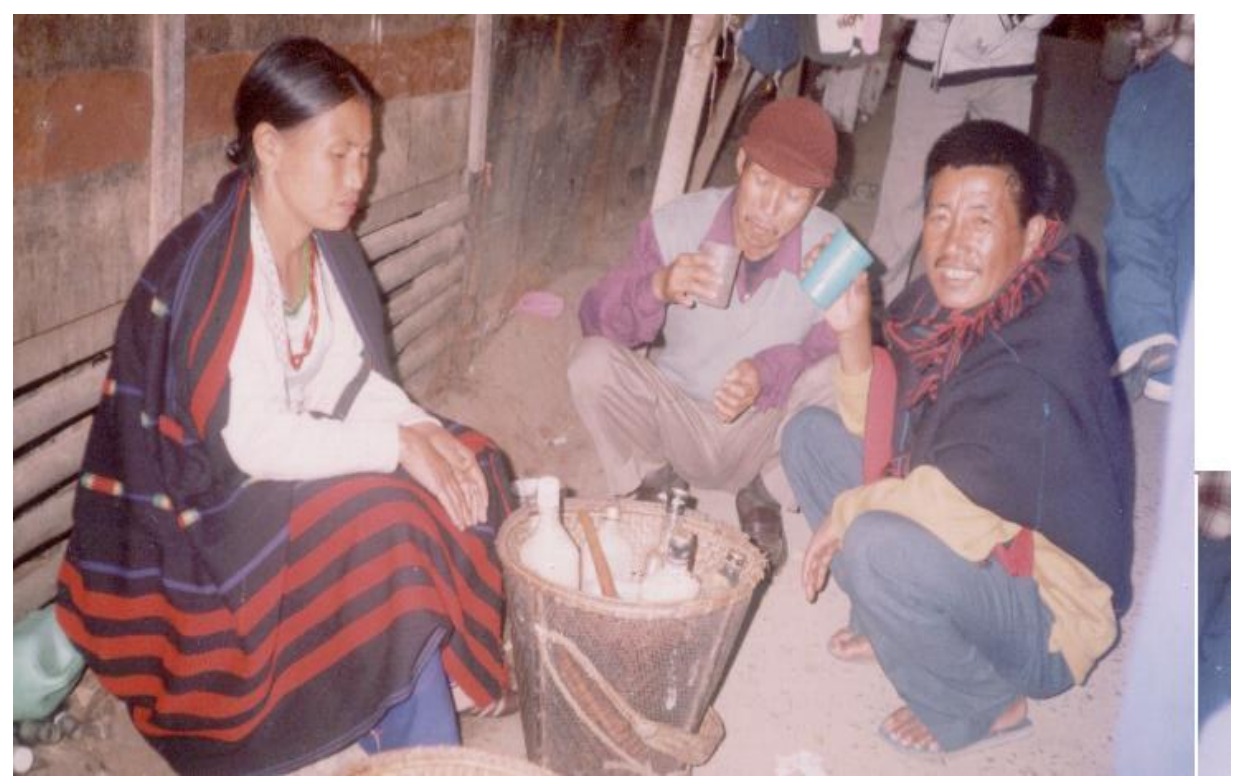

(b) Naga woman selling Nduijao in Haflong bazaar, Haflong (Dima Hasao ) 
Fig. 2 Naga woman selling Nduijao in Haflong bazaar, Haflong (Dima Hasao)

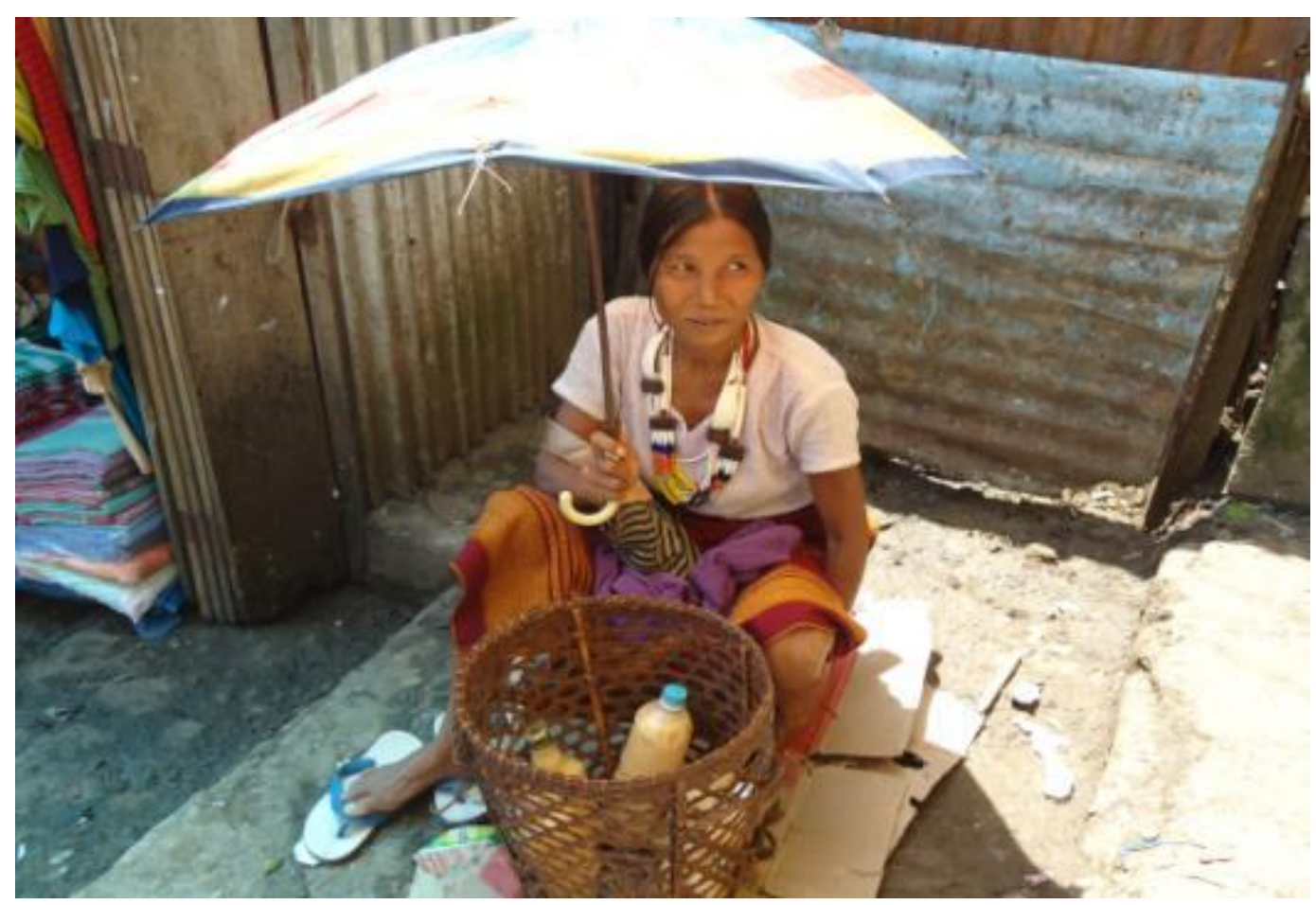

Fig. 3 Starter ready for sale.

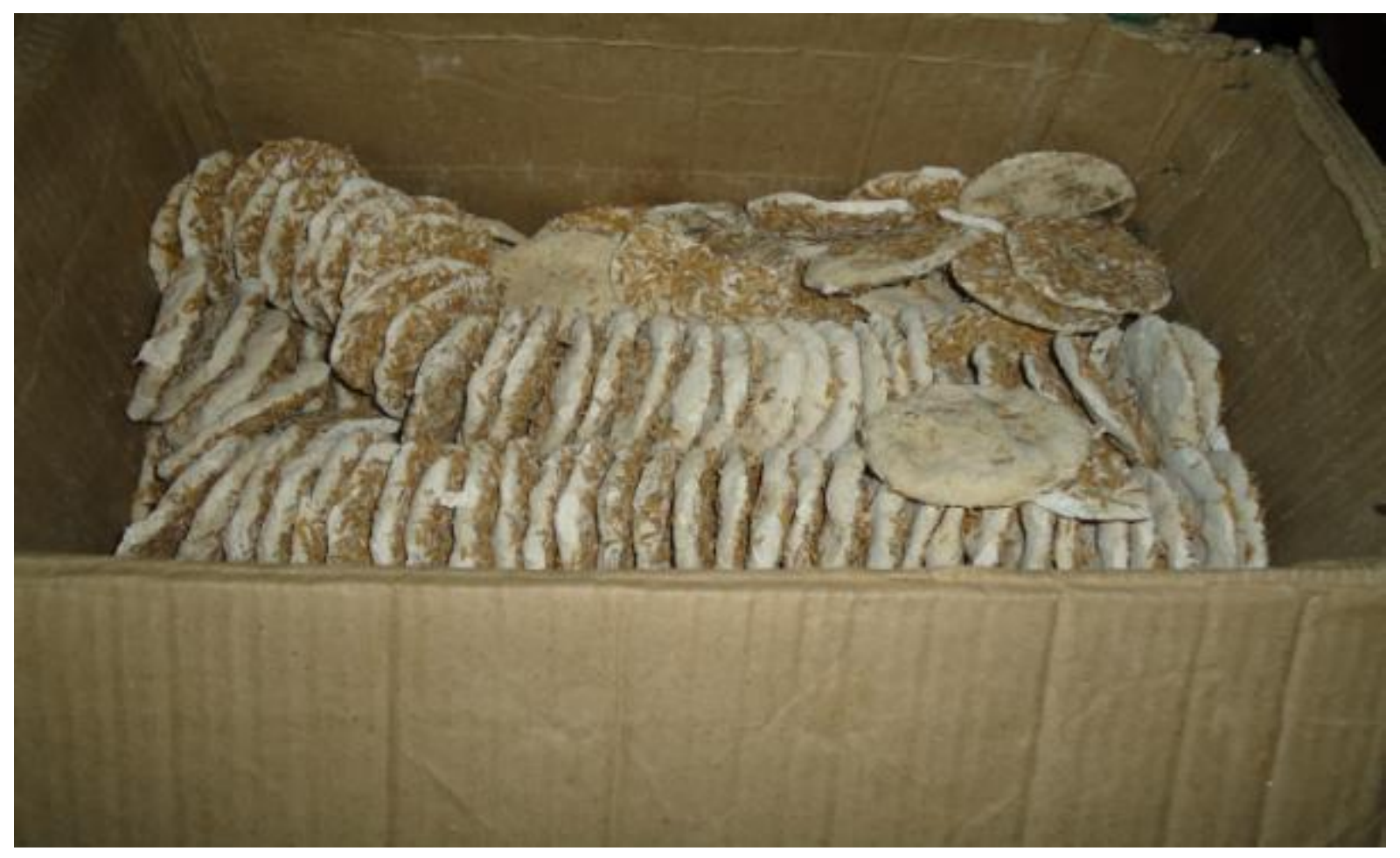


Saccharomyces have a primary role in alcohol fermentation. $C$. glabrata, nonSaccharomyces yeast is a moderate alcohol producer, which has also been recovered from Nduijao, indicating that it is involved in alcohol production. May be nonSaccharomyces yeast might contribute to flavour or aroma formation in the alcohol beverage (Rojas et al., 2001) (Table 2). This starter making technology reflect the traditional method of subculturing desirable inocula from previous batch to new culture using rice as base substrates. Nduijao the popular drink is believed to be good tonic for ailing persons and post-natal women also. Because of high calorie, they consume the popular drink Nduijao to regain the strength.

Minerals content between fermented alcoholic beverage and cooked rice were also checked. Higher minerals content in Nduijao indicate contribution of mineral intake in the daily diet of the local people of the hill district. Yeasts and molds play a major role in the fermentation of foods during which there is bio-enrichment leading to the production of proteins, vitamins, minerals, aroma, alcohols, acids, esters and also improvements in digestibility, preservation, and organoleptic properties. May be, because of the presence of yeasts and Lactic Acid Bacteria (LAB)present in the Fermented foods and alcoholic beverages, the Ethnic foods are safe to eat.

\section{Acknowledgement}

I would like to offer my heartfelt thanks to the villager's of Dima Hasao District of Assam including Gaon Burah's for helping me constantly in this research work. I am thankful to Prof. G.D. Sarma Sir (my Research Guide ) Vice Chancellor, Bilaspur University, Bilaspur, Prof. J. P. Tamang Sir (my Research Guide ) Dean, School of Microbiology , Sikkim University, Gangtok and my husband Dr. Mithilesh chakrabarty of
Maibong Degree College, Maibong, Dima Hasao, for guiding and supporting me in this research Work. I am also thankful to UGC NERO, Ghy, for granting me the Minor research Project, for carry over the research work.

\section{References}

Aidoo, Kofi E. and Nout, M.J.R. 2010. Functional Yeasts and Molds in Fermented Foods and Foods and Beverages. In: Fermented Foods and Beverages of the World. Eds: Tamang, J.P. and Kailasapathy, K. CRC Press, Taylor \& Francis Group, New York, pp. $144-145$.

Chakrabarty, J. 2011. Microbiological and Nutritional Analysis of Some Fermented Foods Consumed by Different Tribes of North Cachar Hills District of Assam, Assam University, Silchar, Assam, Phd Thesis.

Chakrabarty, J., Sharma, G.D. and Tamang, J.P. 2011. Traditional knowledge of ethnic people of North Cachar Hills District of Assam on fermentation of alcoholic beverages. In: Status and Conservation of Biodiversity in North East India, Chapter 16 (Eds: M. Dutta Choudhury, G.D. Sharma, S. Choudhury and A. D. Talukdar. Publisher Swastik Publications, New Delhi, p. 200-211 (ISBN:9 78-9381084-10-6.

Chakrabarty, J., Sharma, G.D. and Tamang, J.P. 2014. Traditional technology and product characterization of some lesserknown ethnic fermented foods and beverages of North Cachar Hills District of Assam. Indian J. Traditional Knowledge, 13(4): 706-715 Impact factor 0.492 .

Deak, T. 1991. Food born yeast. Adv. Appl. Microbiol., 36: 179-278. 
Hadisepoetro, E.S.S., Takada, N. and Oshima, Y. 1979. Microflora in ragi and usar. $J$. Fermentation Technol., 57: 251-259.

Hesseltine, C.W. and Kurtzman, C.P. 1990. Yeasts in amylolytic food starters. Annls. Inst. Biol. Uni. Nac. Antón. México Ser. Bot., 60: 1-7.

Hesseltine, C.W., Rogers, R. and Winarno, F.G. 1988. Microbiological studies on amylolytic Oriental fermentation starters. Mycopathologia, 101: 141-155.

Kurtzman, C.P. and Fell, J.W. 1998. The Yeast, A Taxonomic Study, $4^{\text {th }}$ edition. Elsevier Science, Amsterdam.

Rojas, V., Gil, J.V., Pinaga, F., Manzanares, P., 2001. Studies on acetate ester production by non-Saccharomyces wine yeasts. Int J. Food Microbiol., 70: 283289.

Saono, S., Gandjar, I., Basuki, T. and Karsono, H. 1974. Mycoflora of ragi and some other traditional fermented foods of Indonesia. Annales Bogorienses, (4): 187-204.

Tsuyoshi, N., Fudou, R., Yamanaka, S., Kozaki, M., Tamang, N., Thapa, S. and Tamang, J.P. 2005. Identification of yeast strains isolated from marcha in Sikkim, a microbial starter for amylolytic fermentation. Int. J. Food Microbiol., 99(2): 135-146.

Tamang, J.P. and Kailasapathy, K. Editors) 2010. Fermented Foods and Beverages of the World. CRC Press, Taylor \& Francis Group, New York, pages 144145.
Tamang, J.P. and Sarkar, P.K. 1996. Microbiology of mesu, a traditional fermented bamboo shoot product. Int. J. Food Microbiol., 29: 49-58. IF: 3.011.

Tamang, J.P., Thapa, S., Tamang, N. and Rai, B. 1996. Indigenous fermented food beverages of Darjeeling hills and Sikkim: process and product characterization. J. Hill Res., 9(2): 401411.

Thapa, S., Tamang, J.P. 2004. Product characterization of kodo ko jaanr: fermented finger millet beverage of the Himalayas. Food Microbiol., 21: 617622.

Thompson, J.D., Higgins, D.G., Gibson, T.J. 1994. CLUSTAL W.

Thapa, S. and Tamang, J.P. 2006. Microbiological and physico-chemical changes during fermentation of kodo ko jaanr, a traditional alcoholic beverage of the Darjeeling hills and Sikkim. Indian J. Microbiol., 46(4): 333-341.

Tsuyoshi, N., Fudou, R., Yamanaka, S., Kozaki, M., Tamang, N., Thapa, S. and Tamang, J.P. 2005. Identification of yeast strains isolated from marcha in Sikkim, a microbial starter for amylolytic fermentation. Int. J. Food Microbiol., 99(2): 135-146.

Yarrow, D. 1998. Methods for the isolation, maintenance and identification of yeasts. In: The Yeast, a Taxonomic Study, $4^{\text {th }}$ edition, (Eds: Kurtzman, C.P. and Fell, J.W. Elsevier Science, Amsterdam, pp. 77-105.

\section{How to cite this article:}

Jayasree Chakrabarty. 2017. Identification of Yeast Strain Isolated from Nduiyi of Dima Hasao District of Assam. Int.J.Curr.Microbiol.App.Sci. 6(3): 587-594. doi: https://doi.org/10.20546/ijcmas.2017.603.068 